\title{
Analisis Konsumsi Energi Listrik Universal Milling Machine Pada Berbagai Keadaan Operasi dan Parameter Pemesinan
}

\author{
Dimas Rizky Hermanto ${ }^{1}$, Yanuar Burhanuddinn ${ }^{2, *}$, Suryadiwansa Harun², Gusri Akhyar Ibrahim² \\ 1. PT. Pembangkitan Jawa Bali (PJB) UP Muara Karang \\ 2. Jurusan Teknik Mesin, Fakultas Teknik, Universitas Lampung \\ Jln. Prof.SumantriBrojonegoro No. 1 Gedung H FT Lt. 2 Bandar Lampung \\ *Corresponding author: yanuarb64@gmail.com
}

\begin{abstract}
Abstrak
Penelitian ini dilakukan dengan tujuan melihat pengaruh kondisi mesin dan variasi parameter pemesinan terhadap konsumsi daya listrik mesin frais universal Milko 12. Pengujian pemotongan dilakukan pada baja karbon SS400 dengan tiga kondisi operasi yaitu kondisi idle, kondisi meja bergerak dan kondisi melakukan pemotongan, dimana pada masing-masing kondisi tersebut dibagi lagi menjadi tiga variasi kecepatan spindel, laju pemakanan, dan kedalaman pemotongan. Penelitian dilakukan dengan menggunakan mesin frais konvensional Universal Milko-12.Hasil penelitian menunjukan bahwa konsumsi daya dan temperatur mesin meningkat seiring waktu proses dan peningkatan kecepatan spindel. Pada kondisi pemotongan, selain peningkatan kecepatan spindel peningkatkan kecepatan gerak meja dan kedalaman potong menyebabkan peningkatan temperatur dan konsumsi daya pemotongan.
\end{abstract}

Kata kunci: Paremeter pemesinan, termografi, konsumsi energi

\section{PENDAHULUAN}

Sektor industri hingga saat ini merupakan sektor yang mendominasi konsumsi energi di Indonesia, di mana porsinya mencapai 49,4 persen dari total konsumsi Energi Nasional. Industri di Indonesia yangmenggunakan energi sebagian besarnya merupakan industri yang berbasis manufaktur[1]. Besarnya nilai konsumsi energi dalam industri manufaktur dikarenakan proses pembuatan produk manufaktur untuk dapat beroperasi dilakukan dengan bantuan peralatan dan mesin yang memerlukan energi. Sedangkanhampir seluruh proses produksi pembuatan produk manufaktur melakukan proses pemesinan [2]. Secara garis besar energi input dalam suatu proses pemesinan (energi listrik) ditransformasikan menjadi kerja berguna, dalam perwujudan bentuk komposisi produk, limbah serta panas buang [3]. Salah satu cara umum dalam penelitian untuk mengidentifikasi konsumsi energi input tersebut serta memperoleh pengukuran yang optimal yaitu dengan menganalisa profil energi mesin mesin perkakas [4]. Energi listrik dalam proses pemesinan dihitung berdasarkan seberapa besar konsumsi daya yang digunakan dalam peride waktu proses.Dalam prosesnya, nilai daya listrik tidak $100 \%$ ditransformasi menjadi daya mekanik berguna untuk proses pemotongan material, dimana selama proses juga terdapat kehilangan energi akibat gesekan yang terjadi pada elemen mesin yang berputar yang bertransformasi menjadi panas. Kemudian daya berguna tersebut digunakan kembali sebagai bentuk energi pemotongan spesifik yang besarnya hanya $10 \%-15 \%$ [5]. dimana sisanya bertransformasi menjadi panas yang terdistribusi pada pahat, benda kerja, dan geram. Berdasarkan hal tersebut dapat dikatakan bahwa perilaku termal (thermal behaviour) mesin perkakas dapat menjadi gambaran besarnya konsumsi energi selama proses pemesinan berlangsung seperti yang telah diungkapkan oleh [6].

Melihat hubungan tersebut, maka penulis tertarik untuk melihat pengaruh konsumsi energi terhadap temperatur mesin dan proses pemotongan. Untuk dapat mengetahui hubungan profil transformasi energi tersebut dalam penelitian ini dilakukandua metode pemantauan yaitu konsumsi daya dan termografi. Dengan kedua metode pemantauan tersebut maka akan terlihat hubungan transformasi energi input berupa daya listrik menjadi panas pada struktur mesin perkakas dan proses pemotongan dengan variasi parameter pemesinan yang telah ditentukan dimana sesuai dengan tujuan dari penelitian.

\section{METODE PENELITIAN}

Mesin yang digunakan dalam penelitian ini yaitu mesin frais konvensional universal dengan tipe MILKO 12. Material yang digunakan dalam penelitian ini yaitu baja karbon rendah SS400 dengan nilai kekerasan $160 \mathrm{HB}$. Pahat yang digunakan merupakan jenis HSS 4 bilah (flutes) dengan diameter $16 \mathrm{~mm}$. Pengukuran temperatur menggunakan kamera termografi Cheap-Thermocam 
V4. Pengukuran arus dilakukan pada kabel input dan kabel suplai motor listrik mesin, sedangkan untuk pemantauan termografi, kamera diletakan didepan mesin tepat berhadapan dengan proses pemotongan material seperti ditunjukan pada gambar 1 .

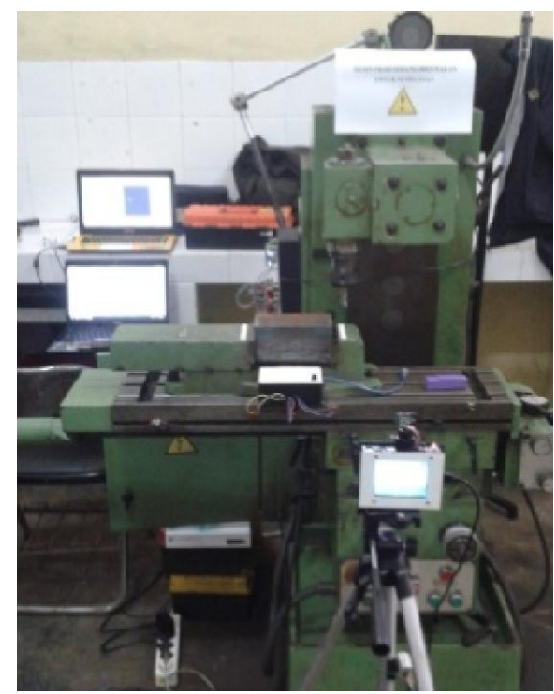

Gambar 1. Set-up Eksperimen

Pengukuran arus dan tegangan menggunakan clamp-on multimeter Mastech MS2115B dan alat pemantau arus yang dibuat dengan menggunakan mikrokontroller arduino dan sensor SCT-013-030 [7] dimana error pengukuran dari pengujian menunjukan nilai dibawah $1 \%$. Data nilai arus terekam secara real-time dengan menggunakan software PLX-DAQ dan PC-Link Mastech MS2115B.

Pemantauan dibagi menjadi tiga kondisi mesin yaitu idle spindel, idle spndle dengan meja bergerak, dan kondisi pemotongan. Dari tiap-tiap kondisi mesin tersebut, kecepatan spindel dan kecepatan gerak meja akan divariasikan. Untuk kondisi pemotongan akan ditambah dengan variasi kedalaman pemotongan pada. Tabel 1 meunjukan variasi parameter pemesinan yang digunakan dalam penelitian. Metode analisa data hasil pemantauan daya rata-rata dan pemantauan termografi dilakukan secara kualitatif.

Tabel 1. Parameter proses pemesinan

\begin{tabular}{cccccccccc}
\hline Vf & \multicolumn{3}{c}{$128 \mathrm{rpm}$} & \multicolumn{3}{c}{$910 \mathrm{rpm}$} & \multicolumn{3}{c}{$1700 \mathrm{rpm}$} \\
\cline { 2 - 9 }$(\mathrm{mm} / \mathrm{min})$ & \multicolumn{2}{c}{$\mathrm{a}_{\mathrm{p}}(\mathrm{mm})$} & \multicolumn{2}{c}{$\mathrm{a}_{\mathrm{p}}(\mathrm{mm})$} & \multicolumn{2}{c}{$\mathrm{a}_{\mathrm{p}}(\mathrm{mm})$} \\
\hline 20 & 0,5 & 1 & 1,5 & 0,5 & 1 & 1,5 & 0,5 & 1 & 1,5 \\
145 & 0,5 & 1 & 1,5 & 0,5 & 1 & 1,5 & 0,5 & 1 & 1,5 \\
365 & 0,5 & 1 & 1,5 & 0,5 & 1 & 1,5 & 0,5 & 1 & 1,5 \\
\hline
\end{tabular}

\section{HASIL DAN PEMBAHASAN}

\section{Kondisi Idle.}

Grafik daya rata-rata untuk variasi kecepatan spindel $1700 \mathrm{rpm}$ selama 30 menit yang ditunjukan pada gambar 2 menunjukan nilai yang konstan hingga akhir proses sebesar 1,93. Pada awal dihidupkannya mesin terlihat bahwa terjadi kenaikan daya hingga $10,4 \mathrm{~kW}$ hal ini terjadi akibat arus inrush.

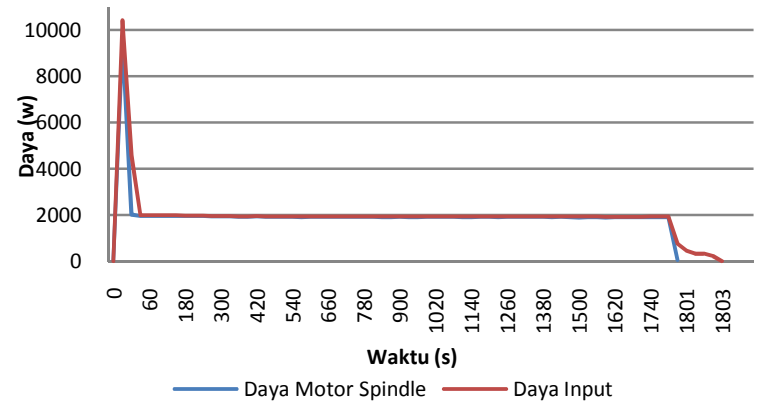

Gambar 2. Daya rata-rata Kondisi Idle n $=1700 \mathrm{rpm}$

Secara keseluruhan, grafik menunjukan bahwa semakin tinggi putaran spindel, nilai arus dan daya juga meningkat, dimana pada kecepatan $128 \mathrm{rpm}$ $1700 \mathrm{rpm}$ masing masing memiliki rentang nilai peningkatan daya rata rata sebesar $1,8 \mathrm{~kW}-2,0 \mathrm{~kW}$. Semakin lama waktu proses, konsumsi daya akan semakin besar.

Hasil pemantauan termografi ditunjukan pada gambar 3 berupa gambar termal yang menunjukan bahwa temperatur tertinggi terjadi pada gearbox spindel arbor. Semakin tinggi putaran spindel maka temperatur meningkat secara signifikan dalam waktu yang lebih singkat. Hal tesebut dapat terjadi karena gesekan akan lebih besar terjadi pada putaran spindel yang tinggi, sehingga panas pada elemen mesin yang berotasi (bearing, gear, dll) terjadi lebih cepat. Grafik temperatur masing masing variasi kecepatan spindel ditunjukan pada gambar 4 untuk waktu idle 30 menit dimana masing masing kecepatan spindel $128 \mathrm{rpm}, 910 \mathrm{rpm}$, dan $1700 \mathrm{rpm}$ menunjukan nilai $33^{\circ} \mathrm{C}, 47^{\circ} \mathrm{C}$ dan $49^{\circ} \mathrm{C}$.

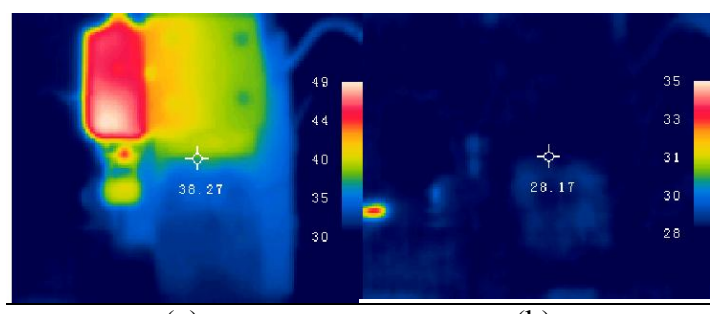

(a)

(b)

Gambar 3. Gambar termal Kondisi Idle Spindel 30 menit $n$ $=1700 \mathrm{rpm} ;$ (a) awal, (b) akhir 


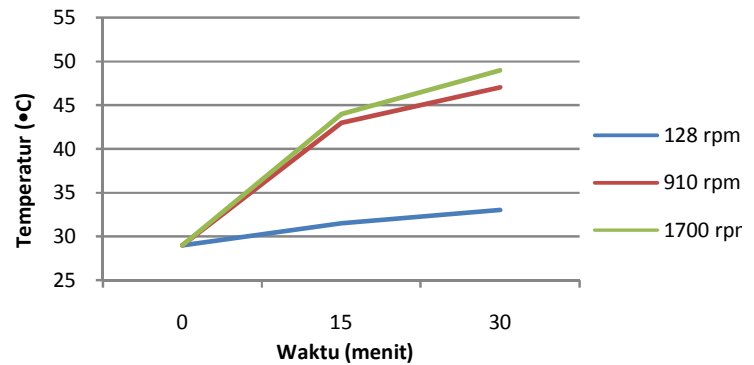

Gambar 4. Grafik Temperatur Spindel Arbor 30 Menit kondisi idle

Dari grafik pada gambar 4 menunjukan bahwa tempertur meningkat seiring waktu proses. Peningkatan temperatur tersebut dapat menyebabkan pengurangan viskositas pelumasan sehingga apabila gesekan terjadi terus menerus maka motor spindel akan mengkonsumsi daya yang lebih besar akibat beban mekanik akibat gesekan.

\section{Kondisi Idle Meja Bergerak}

Grafik daya rata-rata untuk variasi kecepatan spindel $1700 \mathrm{rpm}$ dengan kecepatan gerak meja 20 $\mathrm{mm} /$ menit ditunjukan pada gambar 5 . Terlihat bahwa daya pada awal proses meningkat hingga 11,9 $\mathrm{kW}$. Grafik menunjukan tiga variasi gerakan meja. Kenaikan dan penurunan daya rata rata terjadi hingga akhir proses. Hal ini dapat terjadi karena stabilitas suplai daya input dapat sewaktu waktu naik dan turun mengikuti kualitas suplai listrik dari pembangkit.

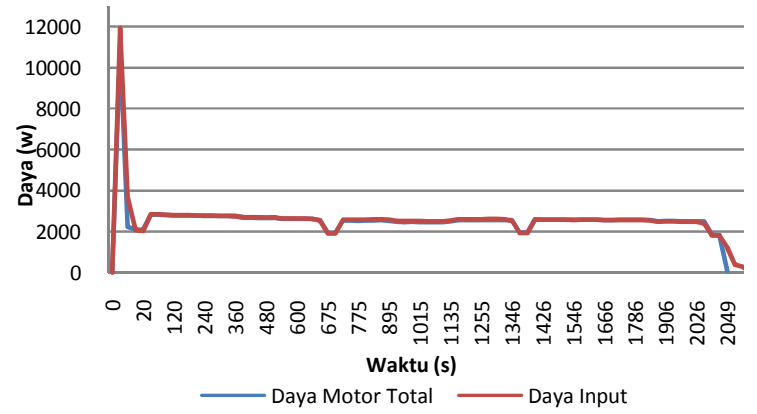

Gambar 5. Daya rata-rata Kondisi Idle Meja Bergerak $\mathrm{n}=1700 \mathrm{rpm}, \mathrm{V}_{\mathrm{f}}=20 \mathrm{~mm} /$ menit

Secara keseluruhan, daya rata-rata kondisi idle meja bergerak menunjukan peningkatan seiring meningkatnya putaran spindel dengan rentang nilai minimum 2,5 kW hingga 2,8 kW. Konsumsi daya lebih besar karena motor penggerak meja dihidupkan, selain itu waktu pengujian yang lebih lama dari waktu teoritis menyebabkan konsumsi daya juga semakin besar.
Hasil pemantauan termografi kondisi idle meja bergerak pada gambar 6 menunjukan bahwa temperatur mengalami peningkatan hingga $51^{\circ} \mathrm{C}$ dibandingkan pada kondisi idle spindel yang diwakili warna putih kemerahan pada gearbox spindel arbor. Peningkatan tersebut terjadi akibat waktu proses pemesinan yang lebih lama dari waktu teoritis proses.

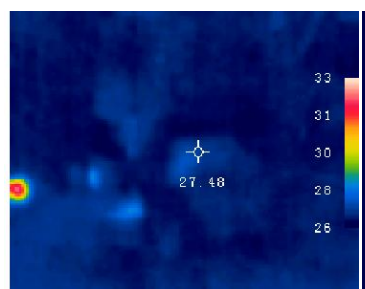

(a)

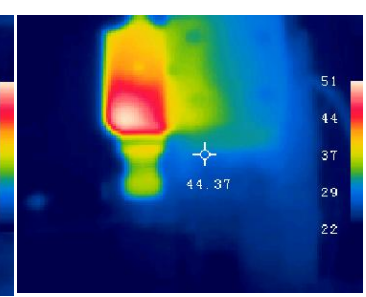

(b)
Gambar 6. Gambar termal Kondisi Idle Meja Bergerak $\mathrm{n}=1700 \mathrm{rpm}, \mathrm{V}_{\mathrm{f}}=20 \mathrm{~mm} / \mathrm{menit}$; (a). Awal, (b) akhir

Total waktu untuk gerak meja $20 \mathrm{~mm} /$ menit , $145 \mathrm{~mm} /$ menit dan $365 \mathrm{~mm} /$ menit menjadi 34 menit, 5,95 menit dan 3 menit. Temperatur pada 34 menit untuk masing masing kecepatan spindel $128 \mathrm{rpm}$, $910 \mathrm{rpm}$, dan $1700 \mathrm{rpm}$ sebesar $31{ }^{\circ} \mathrm{C}, 46{ }^{\circ} \mathrm{C}$ dan $51^{\circ} \mathrm{C}$.

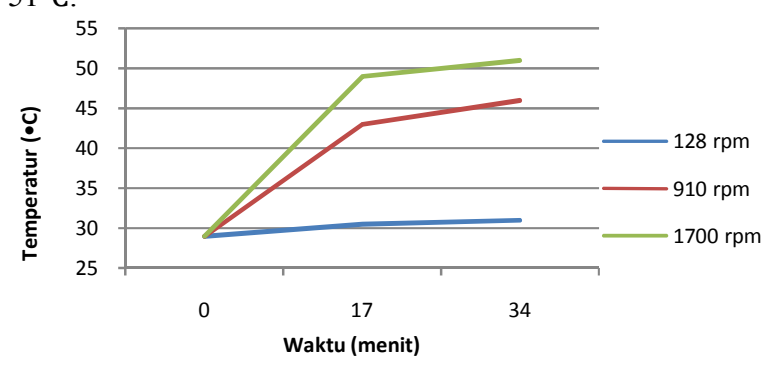

Gambar 7. Grafik Temperatur Spindel Arbor 30 Menit kondisi idle meja bergerak $\mathrm{V}_{\mathrm{f}}=20 \mathrm{~mm} / \mathrm{menit}$

Dari gambar 7 diatas, terlihat kembali bahwa meningkatnya kecepatan spindel ditambah dengan waktu proses yang lebih lama akan berdampak terhadap peningkatan temperatur dari mesin.

\section{Kondisi Melakukan Pemotongan}

Pada kondisi pemesinan grafik nilai daya ratarata menunjukan trend yang peningkatan dan penurunan yang dipengaruhi oleh variasi kedalaman pemotongan. Nilai daya awal menunjukan sebesar 12 kW. Dari grafik yang ditunjukan pada gambar 8 terlihat bahwa terdapat tiga variasi kedalaman pemotongan yaitu $0,5 \mathrm{~mm}, 1 \mathrm{~mm}$, dan $1,5 \mathrm{~mm}$. Nilai daya rata-rata mengalami peningkatan seiring meningkatnya kedalaman pemotongan. Nilai daya yang cenderung tinggi pada awal pemotongan merupakan kondisi dimana pahat menerima beban pemotongan material, kemudian nilai daya justru cenderung turun pada trend selanjutnya. 
Nilai penurunan daya tersebut disebabkan oleh umur pahat yang berkurang, sehingga pada grafik tersebut menunjukan bahwa pahat sudah tidak lagi melakukan pemotongan akibat mata potong yang sudah habis, sehingga kedalaman pemotongan juga berkurang. Nilai daya $3,1 \mathrm{~kW}$ tersebut merupakan daya tertinggi yang terjadi pada variasi kecepatan spindel $1700 \mathrm{rpm}$ dengan kecepatan gerak meja 20 $\mathrm{mm} / \mathrm{menit}$, dan kedalaman potong $1,5 \mathrm{~mm}$. Dari trend grafik tersebut dapat diambil sebuah analisa bahwa keausan pahat memang dapat meningkatkan konsumsi daya pemotongan, namun apabila umur pahat sudah berkurang maka daya akan cenderung menurun kembali.

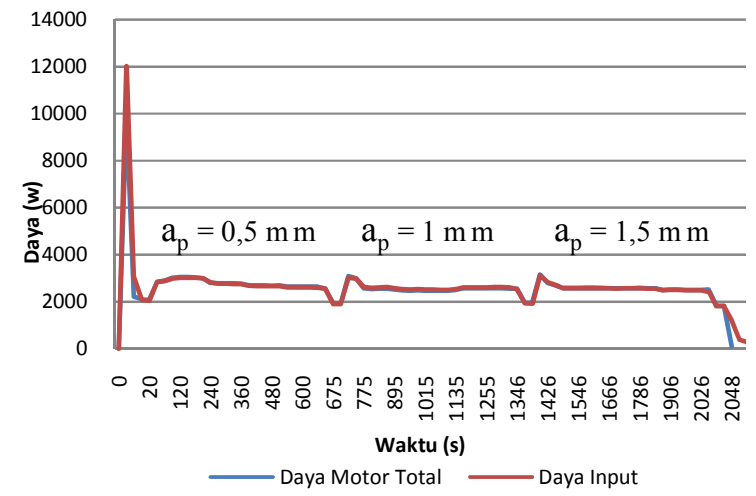

Gambar 8. Daya rata-rata Kondisi Pemesinan $\mathrm{n}=1700 \mathrm{rpm}, \mathrm{V}_{\mathrm{f}}=20 \mathrm{~mm} / \mathrm{menit}$

Dari keseluruhan variasi parameter pemesinan, hasil pemantauan daya rata-rata kondisi pemesinan menunjukan peningkatan nilai daya ratarata dengan rentang nilai minimum $2,6 \mathrm{~kW}$ hingga maksimum $3,1 \mathrm{~kW}$

Jika pada kondisi idle dan idle meja bergerak pemantauan difokuskan pada distribusi kenaikan temperatur mesin, Pada kondisi pemesinan pemantauan difokuskan pada proses pemotongan. Temperatur pemotongan yang tinggi menjadi indikasi besarnya daya pemotongan dan menjadi penyebab keausan pahat. Temperatur pemotongan tertinggi terjadi pada awal proses dengan kedalaman potong maksimum $1,5 \mathrm{~mm}$ sebesar $300^{\circ} \mathrm{C}$.

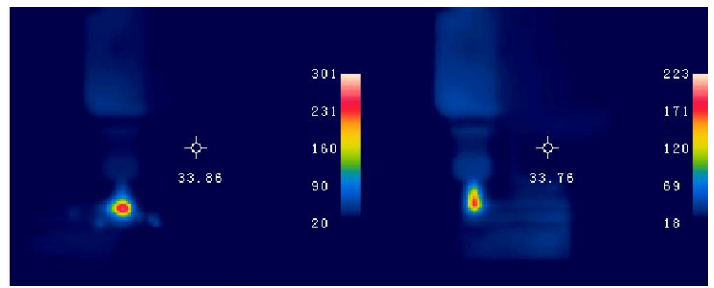

(a)

(b)

Gambar 9. Gambar termal Kondisi Pemesinan $\mathrm{n}=1700 \mathrm{rpm}, \mathrm{V}_{\mathrm{f}}=20 \mathrm{~mm} / \mathrm{menit}, \mathrm{a}_{\mathrm{p}}=1,5 \mathrm{~mm}$ (a). Awal , (b) Akhir
Grafik temperatur pemotongan pada gambar 10 menunjukan trend kenaikan temperatur pada awal pemotongan dari tiap masing-masing kedalaman potong. Hal ini berbanding lurus dengan trend grafik daya rata-rata proses pemotongan yang ditampilkan pada gambar 8, dimana pada waktu yang sama peningkatan daya rata-rata terjadi bersamaan saat temperatur pemotongan juga meningkat. Ini membuktikan bahwa temperatur pemotongan yang tinggi menjadi indikasi peningkatan daya pemotongan yang juga tinggi.

Dari keseluruhan data yang didapat selama proses pemotongan material, kecepatan gerak meja memiliki pengaruh yang besar terhadap daya pemotongan dan temperatur pemotongan. Temperatur pemotongan yang tinggi dapat menandakan bahwa daya pemotongan juga besar. Pada data untuk variasi kecepatan spindel $128 \mathrm{rpm}$ dan $910 \mathrm{rpm}$ temperatur pemotongan menunjukan peningkatan meningkatnya kecepatan gerak meja, sedangkan pada kecepatan spindel $1700 \mathrm{rpm}$ temperatur pemotongan menurun seiring meningkatnya kecepatan gerak meja. Berdasarkan hasil penelitian yang dilakukan oleh Badrinathan, (2014) Hal tersebut terjadi karena putaran spindel yang tinggi pada gerak meja yang cepat menyebabkan penurunan gaya pemotongan, sehingga daya pemotongan rendah dan temperatur juga lebih rendah.

Meskipun terlihat bahwa pengaruh variasi parameter pemesinan memiliki dampak terhadap daya pemotongan dan juga temperatur pemotongan, namun terdapat faktor lain yang dapat mempengaruhi konsumsi daya selama proses, diantaranya yaitu faktor efisiensi mesin perkakas sendiri serta stabilitas suplai energi listrik pembangkit. Dimana tidak menutup kemungkinan data kondisi idle dapat lebih tinggi dari data dari proses pemotongan material, meskipun seharusnya pada saat pemotongan material motor spindel menerima beban yang lebih dibandingkan saat idle. Diluar kedua faktor tersebut, sebagai langkah untuk meminimalisir konsumsi energi dan biaya dalam proses pemesinan, perlu dilakukan pemilihan parameter pemotongan yang tepat dan terbaik.

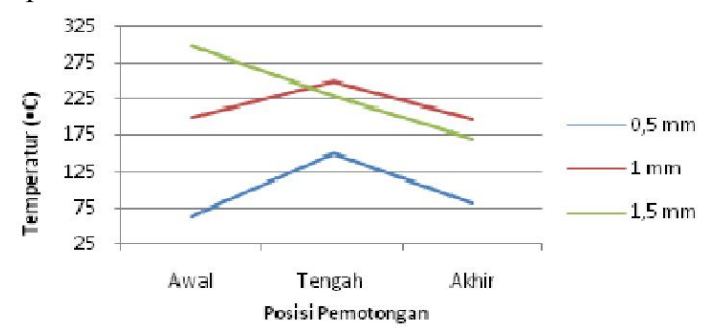

Gambar 10. Grafik Temperatur Pemotongan $\mathrm{n}=1700 \mathrm{rpm}, \mathrm{V}_{\mathrm{f}}=20 \mathrm{~mm} / \mathrm{menit}$ 


\section{KESIMPULAN}

Dari penelitian yang telah dilakukan didapat beberapa kesimpulan antara lain :

1. Peningkatan kecepatan spindel dan lama waktu proses berpengaruh terhadap peningkatan nilai daya. Hal ini juga sebanding dengan kenaikan temperatur mesin.

2. Pada kondisi pemesinan, peningkatan nilai daya tinggi. Begitu juga sebaliknya nilai daya mengalami penurunan seiring turunnya temperatur pemotogan sebagai akibat dari berkuraungnya umur pahat. Sehingga indikasi peningkatan nilai daya dan temperatur dapat digunakan sebagai pemantauan prediksi untuk tingkat keausan dan umur pahat pada temperatur dan daya tertinggi saat proses pemotongan.

3. Pengaruh kenaikan temperatur dari masing masing kecepatan spinde dan waktu proses tidak selamanya menjadi indikasi kenaikan nilai konsumsi daya. Nilai daya bisa naik dan turun pada waktu proses, meskipun sebenarnya nilai nya seharusnya menunjukan peningkatan akibat beban, namun akibat ketidakstabilan suplai tenaga listrik pengaruh tersebut menjadi tidak terlihat.

\section{Daftar Pustaka}

[1] Kementerian ESDM. 2012. Buku perencanaan kebutuhan energi sector industri dalam rangka akselerasi industrialisasi. Biro Perencanaan Kementrian Perindustrian Republik Indonesia.

[2] Zulhendri , Kiswanto,G., Yazamendra, R. 2007. Pengaruh Tipe Pahat dan Arah Pemakanan Berkontur pada Pemesinan Milling Awal dan Akhir Terhadap Kekasaran Permukaan . Jurnal Teknik Mesin. 4(1):15-22.

[3] Gutowski, T. G., Dahmus, J. B., Thiriez, A. 2006. Electrical Energy Requirements for Manufacturing Processes. Leuven, Belgium, pp. 623-627. Proceedings of the 13th CIRP Conference on Life Cycle Engineering, ed. By Duflou, J. et al.

[4] Herrmann, C; Thiede, S., Zein, A, Ihlenfeldt, S., Blau, P., 2009. Energy Efficiency of Machine Tools: Extending the Perspective. Grenoble, France. Publiziert in / published in: Tagungsbericht: Proceedings of the 42nd CIRP International Conference on Manufacturing Systems, June $3-5$
[5] Gutowski, T. G., Dahmus, J. B., Thiriez, A. 2004. AN ENVIRONMENTAL ANALYSIS OF MACHINING. ASME International Mechanical Engineering Congress and RD\&D Expo November Anaheim, California USA

[6] M. Ess , J. Mayr, S. Weikert, K. Wegener.2012. An Energy Model for the Calculation of Losses and their Effects on Machining Accuracy. Proceedings of the 12th euspen International Conference - Stockholm

[7] Open Energy Monitor. Resources- Electricity Monitoring. https:/openenergymonitor .org/ emon/buildingblocks/ct-and-ac-power-adaptorinstallation-and-calibration-theory

[8] K.S. Badrinathan et al.2014. Study of The Effect of Progressive Feed Rate on The Cutting Force in CNC End Milling of AISI 1045 Steel. 